\section{Growth and Yield of Cultivated Grape with Native Perennial Grasses Nodding Needlegrass or California Barley as Cover Crops}

\author{
Michael J. Costello \\ Cooperative Extension, University of California, 1720 S. Maple Ave., Fresno, \\ CA 93702
}

Additional index words. Vitis vinifera, vineyard, Nassella cernua, Hordeum brachyantherum ssp. californicum

\begin{abstract}
Two California native perennial grasses, nodding needlegrass [Nassella cernua (Stebbins \& R.M. Love) Barkworth] and California barley [Hordeum brachyantherum Nevski ssp. californicum (Covas \& Stebbins) Bothmer, N. Jacobsen \& Seberg], were compared with a conventional grass cover crop, 'Blando' brome (Bromus hordeaceus $\mathbf{L}$.), as well as resident (weedy) vegetation and a clean cultivated control for effects on growth and yield of cultivated grape (Vitis vinifera $\mathrm{L}$. cv. Barbera). Statistical analyses did not reveal yield differences between treatments with floor vegetation (the native grasses, 'Blando' brome, and resident vegetation) and clean cultivation, the cover crop treatments (the native grasses and 'Blando brome') and clean cultivation, nor the native grass treatments versus treatments with non-native floor vegetation ('Blando' brome and resident vegetation). However, there was a significant difference between the two native grasses with the average yield of nodding needlegrass $26.2 \%$ higher than that of California barley. Treatments did not differ in ${ }^{\circ}$ Brix, berry weight, or pruning weight. At the end of the study, vine trunk diameter was $7.1 \%$ higher under the cover crop treatments than resident vegetation. Given these results, in vineyards where a neutral effect on growth or yield is desired, nodding needlegrass would be suitable as a permanent cover crop, whereas California barley would not.
\end{abstract}

Managing floor vegetation is a prime consideration for vineyard managers. The benefits of removing resident (weedy) vegetation are well known: weeds can compete with the vines for water, nutrients, and even light, and the traditional method of protecting vine growth and yield is to keep the vineyard free of floor vegetation either through use of herbicides or cultivation. However, a vineyard floor with no vegetative cover has its drawbacks, which includes increased dust (impeding photosynthesis and increasing vine susceptibility to spider mites) and increased rate of organic matter decomposition leading to a decline in soil structure and poorer water penetration (Gulick et al., 1994). On slopes with no floor vegetation, there is an increased risk of erosion.

It has become common in California for practitioners to maintain vineyard floor vegetation for at least part of the year either by

Received for publication 30 July 2009. Accepted for publication 30 Oct. 2009 .

I thank the University of California Sustainable Research and Education Program, which provided funding for this study.

I thank assistants Jose Cantu, Abebe Gebreheiwet, Kimberly Miyasaki, and Juliet Schwartz and Scott Stewart of Conservaseed (Rio Vista, CA).

Current address: Horticulture and Crop Science Department, Cal Poly State University, 1 Grand Avenue, San Luis Obispo, CA 93407.

e-mail mcostell@calpoly.edu.
Self-reseeding annuals can provide cover cropping benefits while minimizing in-season competition (Bugg et al., 1996). These can be grasses or legumes, which, under nontillage, set seed and senescence in the spring, leaving a dead mulch, which can outcompete weeds. The seed then germinates with the fall rains and a new stand is established. 'Blando' brome, a self-reseeding cover crop commonly used in California vineyards, has been found to use only a moderate amount of water (Gulick et al., 1994; Prichard et al., 1989). However, self-reseeding annuals need to be replanted every few years to revitalize the stand.

A potential alternative cover cropping system for orchards or vineyards in California, and perhaps other regions with a Mediterranean climate, is the use of native perennial grasses. These grasses should be well suited as cover crops in that their phenology is opposite that of the grapevine, i.e., their dormant period is during the summer dry season when the vines are active. Therefore, they should provide the advantages of a perennial cover crop without the disadvantage of excessive competition with the vines for water and nutrients, although this would depend on the degree of native grass summer dormancy. Since the early 1990 s, there has been increased interest in the use of native grasses among commercial orchardists and viticulturists in California (Ingels, 1998).

The object of this study was to test the competitive effect on the grapevines of two California native grasses, nodding needlegrass and California barley. Each is a perennial bunch grass, which blooms in midspring and sets seed in late spring. California barley has a maximum height of $0.5 \mathrm{~m}$ and nodding needlegrass $0.8 \mathrm{~m}$ (USDA-NRCS, 2008). These were compared with 'Blando brome', a self-reseeding annual native to Europe; resident vegetation, which consisted of naturalized grasses and forbs from Europe and Asia; and a clean cultivated control. From the same study, data were collected on soil water content and leaf water potential from the nodding needlegrass and clean cultivated treatments and are presented in another paper.

\section{Materials and Methods}

and strawberry clover (Trifolium fragiferum L.) require summer water, making their management all but impractical except in areas with abundant irrigation water or a high soil water table. Non-native grasses maintained during the growing season compete with the grapevines for water and nitrogen and have led to reductions in grapevine vigor and yield. A cover crop of 'Berber' orchardgrass (Dactylis glomerata L.) increased water stress and lowered vigor and yield of ' $\mathrm{Caber}$ net Sauvignon' by $\approx 50 \%$ (Wolpert et al., 1993). Costello and Daane (2003) found summer floor vegetation dominated by barnyard grass (Echinochloa spp.) and large crabgrass [Digitaria sanguinalis (L.) Scopoli] decreased leaf nitrate-nitrogen concentration and vigor of 'Thompson Seedless'.
The experiment was conducted in 1998 and 1999 at the Kearney Agricultural Center in Parlier (Fresno County), CA. Soil type at the site was a Hanford fine sandy loam. The vineyard was a 0.4-ha block, cv. Barbera, planted in 1989 , on $2.1 \mathrm{~m}$ (in row) $\times 3-\mathrm{m}$ (between row) spacing. Vines were trained to a bilateral cordon and spur pruned and trellised with a single catch wire. Plot size was five rows by six vines and treatments were replicated three times in a randomized complete block design. The viticultural climate was categorized as a Winkler Region V with $\approx 2500$ growing degree-days above $10{ }^{\circ} \mathrm{C}$ between 1 Apr. and 31 Oct. in the northern hemisphere (Winkler et al., 1974). 
The cover crops were established in Nov. 1996 planting at a rate of $13.2 \mathrm{~kg} \cdot \mathrm{ha}^{-1}$. Treatments were 1) nodding needlegrass [Nassella cernua (Stebbins \& R.M. Love) Barkworth]; 2) California barley [Hordeum brachyantherum Nevski ssp. californicum (Covas \& Stebbins) Bothmer, N. Jacobsen \& Seberg]; 3) 'Blando' brome; 4) resident vegetation; and 5) a clean cultivated control. Resident vegetation consisted of winter annuals, primarily soft chess (Bromus mollis L.), foxtail barley (Hordeum murinum L. ssp. leporinum), spotted cat's ear (Hypochoeris radicata $\mathrm{L}$.), annual ryegrass [Lolium perenne L. ssp. multiflorum (Lam.) Husnot], filaree (Erodium spp. L.), and cudweed (Gnaphalium sp. L.). Cover crop and resident vegetation management consisted of one mowing in the middle of June of each year.

Vines were drip-irrigated at $80 \%$ of full evapotranspiration throughout the season from 1 May to 1 Nov. of each year. Daily reference evapotranspiration figures were accessed from the California Irrigation Management Information System weather station located on-site and monthly crop coefficient values from Williams et al. (2003). Estimated water applied was $503 \mathrm{~mm}$ in 1998 and 538 mm in 1999.

Between-row weed control in the clean cultivated treatment was undertaken every 2 weeks during the growing season by use of a tractor-drawn rototiller. For the entire study site, in-row weed control was accomplished by application of glyphosate (2.6 kg glyphosate acid equivalent/ha) in March and May applied in a 1-m wide band.

All samples were taken from the middle three rows each plot (with the outer two rows a buffer) and middle four vines of each row (with the outer two vines a buffer). Just before harvest in each year, 50 berries per plot were randomly sampled, weighed, and percent sugar $\left({ }^{\circ}\right.$ Brix $)$ estimated with a handheld refractometer (Leica Microsystems Inc., Buffalo, NY). Yield was estimated by harvesting and weighing the fruit from four randomly selected half-vines per plot (29 Sept. 1998 and 13 Sept. 1999). In January after each field season, four randomly selected vines per plot were pruned and the brush weighed as an estimate of vine vigor. As an estimate of the effect of the cover crops on vine vigor since cover crop establishment, trunk diameter was taken with a pair of digital calipers (Mitutoyo Co., Kanagawa, Japan) in Feb. 2000 measuring four randomly selected vines per plot at a height of $0.3 \mathrm{~m}$.

Yield, berry weight, ${ }^{\circ}$ Brix, and pruning weight were analyzed by repeated measures analysis of variance (ANOVA) using a log 10 transformation and using year as the repeated measures variable and planned orthogonal contrasts for mean separation (PROC GLM; SAS Institute, 2003). For purposes of the orthogonal contrasts, the variable "floor vegetation" pooled the treatments with vineyard floor vegetation (nodding needlegrass, California barley, 'Blando' brome, and resident vegetation), "cover crop" pooled the planted cover crop treatments (nodding needlegrass,
California barley, and 'Blando' brome), "native grasses" pooled the native grasses (nodding needlegrass and California barley), and "non-native floor vegetation" pooled 'Blando' brome and resident vegetation. Trunk diameter data were analyzed by oneway ANOVA (PROC GLM; SAS Institute, 2003). Differences between means were considered significant when $P \leq 0.05$.

\section{Results}

There was a year effect for yield (Table 1) with overall yield $65 \%$ higher in 1999 than 1998. However, there was no yield $\times$ year interaction $(\mathrm{F}=0.92, \mathrm{df}=4,107, P=0.45)$ justifying the repeated measures ANOVA, which was significant (Table 2). Orthogonal contrasts indicated no significant yield differences between "floor vegetation" and clean cultivation, "cover crop" versus resident vegetation, nor "native grasses" versus "non-native floor vegetation" (Table 2). However, there was a significant difference between the two native grasses (Table 2) with the average yield of nodding needlegrass $26.2 \%$ higher than that of California barley (Table 1). Average ${ }^{\circ}$ Brix was $22.71 \pm$ 0.29 (SE of the mean) in 1998 and $20.03 \pm$ 0.41 in 1999 , average berry weight was $2.91 \mathrm{~g}$ $\pm 0.04 \mathrm{~g}$ in 1998 and $2.86 \mathrm{~g} \pm 0.02 \mathrm{~g}$ in 1999 , and average pruning weight per vine was 2.31 $\mathrm{kg} \pm 0.08 \mathrm{~kg}$ in 1998 and $2.21 \mathrm{~kg} \pm 0.06 \mathrm{~kg}$ in 1999. However, ANOVA was not significant among treatments for ${ }^{\circ}$ Brix $(\mathrm{F}=0.23, \mathrm{df}=4$, $8, P=0.91)$, berry weight $(\mathrm{F}=0.55, \mathrm{df}=4,8$, $P=0.70)$, nor pruning weight $(\mathrm{F}=1.79$, $\mathrm{df}=$ $4,53, P=0.144)$. The regression analysis showed a significant relationship between trunk diameter and yield $(\mathrm{y}=-2.2-2.1 \mathrm{x}$, $\left.P<0.01, r^{2}=0.53\right)$, and there was an effect on estimated trunk diameter among treatments with the overall ANOVA significant (Table 3). Treatment comparisons showed no significant difference in trunk diameter between "floor vegetation" and clean cultivation, "native grasses" versus "non-native floor vegetation," nor nodding needlegrass versus 'Blando' brome (Table 3). However, average trunk diameter of "cover crop" was $7.1 \%$ higher than resident vegetation (Table 4).

\section{Discussion}

Results of this study indicate that not all California native grasses function alike as vineyard cover crops. Although nodding needlegrass did not depress yield, California barley did. Therefore, California barley can be included with other cover crops or resident vegetation shown to be competitive with grapevines in California (Costello and Daane, 2003; Wolpert et al., 1993). Although yield was not reduced overall under the resident vegetation, the reduction in trunk diameter indicates that this treatment, too, had a competitive effect. It is not clear why the low trunk diameter in the clean cultivation treatment did not correspond to lowered yield. Because there was no difference among treatments in berry weight, the lower yield with California barley must be the result of either smaller clusters or lower cluster number per vine.

Studies conducted on California native grasses in vineyards have found little negative effect on yield and mixed effects on vigor. Ingels et al. (2005) found that a blend of California brome (Bromus carinatus Hook. \& Arn.), blue wildrye (Elymus glaucus Buckley), and Idaho fescue (Festuca idahoensis Elmer) decreased vigor of drip-irrigated 'Merlot' by $\approx 31 \%$ after 4 years of study but had no effect on yield. This finding suggests that the vines were overly vigorous to begin with and benefitted from some competition from the cover crop. Baumgartner et al. (2008) found no effect on pruning weight nor yield on dripirrigated 'Merlot' after 3 years with either a blend of self-seeding non-native annuals or California native grasses [blue wildrye, California brome, meadow barley (Hordeum brachyantherum Nevski), and red fescue (Festuca rubra L.)]. The lack of negative effect of California barley in that study may have been the result of its status as a member of a blend rather than a stand alone cover crop.

Why California barley had a negative effect on grapevine vigor and yield in the current study, whereas nodding needlegrass did not, is unclear. One possibility would be a difference between the species in degree of summer dormancy. Levitt (1980) categorized drought resistance in plants as "drought avoidance" (i.e., those that maintain high water potential despite low water potential in the environment) and "drought tolerance" (i.e., those that can survive low water potential). Although the mechanisms of drought resistance for nodding needlegrass and California barley are not known, California barley is more commonly found on wetlands or soils with relatively higher summer moisture and nodding needlegrass where summer soil conditions are drier (K.J. Rice, University of California, personal communication). Given that in the current study grape yield was reduced by California barley, this suggests that it took advantage of available soil moisture in the vine root zone in contrast to nodding needlegrass, which did not affect yield. It may be that nodding needlegrass is drought-tolerant, using little summer water regardless of the degree of soil moisture and, using the terminology of Volaire and Norton (2006), exhibits "complete dormancy." This mechanism has been shown experimentally for D. glomerata 'Kasbah' (Norton et al., 2006, 2008). It is possible that California barley is a drought avoider with a "water

Table 1. Mean yield ( $\mathrm{kg} / \mathrm{vine} \pm \mathrm{SE}$ of the mean) among the cover crop, resident vegetation, and clean cultivated treatments for 1998 and 1999.

\begin{tabular}{lcc}
\hline & \multicolumn{2}{c}{ Yield $(\mathrm{kg} /$ vine $\pm \mathrm{SE})$} \\
\cline { 2 - 3 } Treatment & 1998 & 1999 \\
\hline Blando brome & $25.21 \pm 2.48$ & $37.48 \pm 1.75$ \\
Nodding needlegrass & $26.05 \pm 2.62$ & $38.75 \pm 2.91$ \\
Clean cultivation & $21.14 \pm 2.20$ & $38.71 \pm 2.01$ \\
Resident vegetation & $20.41 \pm 2.35$ & $34.28 \pm 3.81$ \\
California barley & $16.92 \pm 1.92$ & $32.75 \pm 2.43$ \\
\hline
\end{tabular}


Table 2. Repeated measures analysis of variance for vine yield ( $\mathrm{kg} / \mathrm{vine} \pm \mathrm{SE}$ of the mean) with comparisons among treatments using orthogonal contrasts. ${ }^{2}$

\begin{tabular}{lccc}
\hline Source of variation & Degrees of freedom & F & $P$ \\
\hline Treatment & 4 & 2.59 & 0.04 \\
Block & 2 & 0.12 & 0.88 \\
Error & 53 & & \\
Contrast & & & \\
$\quad$ Floor vegetation versus clean cultivation & 1 & 0.21 & 0.65 \\
Cover crop versus resident vegetation & 1 & 0.97 & 0.33 \\
$\quad$ Native grasses versus non-native floor vegetation & 1 & 0.41 & 0.52 \\
$\quad$ Nodding needlegrass versus California barley & 1 & 7.00 & 0.01 \\
\hline
\end{tabular}

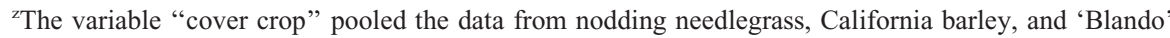
brome. The variable "non-native cover" pooled the data from 'Blando' brome and resident vegetation.

Table 3. Analysis of variance for estimated trunk diameter, taken Jan. 2000, with comparisons among treatments using orthogonal contrasts. ${ }^{\mathrm{Z}}$

\begin{tabular}{lccc}
\hline Source of variation & Degrees of freedom & $\mathrm{F}$ & $P$ \\
\hline Treatment & 4 & 2.54 & 0.05 \\
Block & 2 & 4.17 & 0.02 \\
Error & 53 & & \\
Contrast & & & \\
$\quad$ Cover crop versus clean cultivation & 1 & 0.30 & 0.59 \\
$\quad$ Cover crop versus resident vegetation & 1 & 6.19 & 0.02 \\
$\quad$ Native grasses versus non-native floor vegetation & 1 & 0.03 & 0.87 \\
$\quad$ Nodding needlegrass versus California barley & 1 & 1.27 & 0.27 \\
\hline
\end{tabular}

${ }^{2}$ The variable "cover crop" pooled the data from nodding needlegrass, California barley, and 'Blando" brome. The variable "non-native cover" pooled the data from 'Blando' brome and resident vegetation.

Table 4. Mean trunk diameter $(\mathrm{mm} / \mathrm{vine} \pm \mathrm{SE}$ of the mean) by treatment, Jan. 2000.

\begin{tabular}{lc}
\hline Treatment & Trunk diam $(\mathrm{mm} \pm \mathrm{SE})$ \\
\hline Blando brome & $53.384 \pm 1.080$ \\
Nodding needlegrass & $51.932 \pm 0.917$ \\
California barley & $50.149 \pm 1.627$ \\
Clean cultivation & $50.123 \pm 1.145$ \\
Resident vegetation & $48.393 \pm 1.482$ \\
\hline
\end{tabular}

spender" strategy and may be more appropriately categorized as "incompletely dormant" (Volaire and Norton, 2006).

Nodding needlegrass therefore appears to be a promising candidate as a stand alone permanent cover crop for California vineyards in situations in which a negative effect on grapevine performance is not desired. It was similar to the self-reseeding 'Blando brome' in that it did not have a negative effect on vine growth and yield. The main management difference between these two cover crops would be in seeding frequency: 'Blando' brome has to be reseeded every 3 to 4 years, whereas an established cover crop of nodding needlegrass could conceivably last for 10 years or more. California
Gulick, S.H., D.W. Grimes, D.S. Munk, and D.A. Goldhammer. 1994. Cover-crop-enhanced water infiltration of a slowly permeable fine sandy loam. Soil Sci. Soc. Amer. J. 58:1539-1546.

Ingels, C.A. 1998. Implementation of cover cropping in vineyards: Grower practices, p. 135150. In: Ingels, C., R.L. Bugg, G.T. McGourty, and L.P. Christensen (eds.). Cover cropping in vineyards: A growers handbook. University of California Division of Agriculture and Natural Resources, Oakland, CA.

Ingels, C.A., R.L. Bugg, and F.L. Thomas. 1998. Vineyard cover crops and their uses: Cover crop species and descriptions, p. 8-26. In: Ingels, C., R.L. Bugg, G.T. McGourty, and L.P. Christensen (eds.). Cover cropping in vineyards: A growers handbook. University of California Division of Agriculture and Natural Resources, Oakland, CA.

Ingels, C.A., K.M. Scow, D.A. Whisson, and R.E. Drenovsky. 2005. Effects of cover crops on grapevines, yield, juice composition, soil microbial ecology, and gopher activity. Amer. J. Enol. Viticult. 56:19-29.

Levitt, J. 1980. Responses of plants to environmental stresses. Academic Press, London, UK.

Norton, M.R., F. Lelièvre, S. Fukai, and F. Volaire. 2008. Measurement of summer dormancy in temperate perennial pasture grasses. Aust. J. Agr. Res. 59:498-509.

Norton, M.R., F. Lelievre, and F. Volaire. 2006 Summer dormancy in Dactylis glomerata L., the influence of season of sowing and a simulated mid-summer storm on two contrasting cultivars. Aust. J. Agr. Res. 57:565-575.

Prichard, T.L., W.M. Sills, W.K. Asai, L.C. Hendricks, and C.L. Elmore. 1989. Orchard water use and soil characteristics. Calif. Agr. $43: 23-25$.

SAS Institute. 2003. SAS/STAT user's guide, release 9.1 ed. SAS Institute, Cary, NC.

Baumgartner, K., K.L. Steenwerth, and L. Veilleux. 2008. Cover crop systems affect weed communities in a California vineyard. Weed Sci. 56:596-605.

Bugg, R.L., G. McGourty, M. Sarrantonio, W.T. Lanini, and R. Bartolucci. 1996. Comparison of 32 cover crops in an organic vineyard on the North Coast of California. Biol. Agr. Hort. 13:63-81.

Costello, M.J. and K.M. Daane. 2003. Spider and leafhopper (Erythroneura spp.) response to vineyard ground cover. Environ. Entomol. 32:1085-1098.

Elmore, C.L., D.R. Donaldson, and R.J. Smith 1998. Weed management, p. 107-112. In Ingels, C., R.L. Bugg, G.T. McGourty, and L.P. Christensen (eds.). Cover cropping in vineyards: A growers handbook. University of California Division of Agriculture and Natural Resources, Oakland, CA.
USDA-NRCS. 2008. Plants database. US Department of Agriculture-Natural Resources Conservation Service, Washington, DC. 2 Nov. 2009. $<$ http://plants.usda.gov/>.

Volaire, F. and M. Norton. 2006. Summer dormancy in perennial temperate grasses. Ann. Bot. (Lond.) 98:927-933.

Williams, L.E., C.J. Phene, D.W. Grimes, and T.J. Trout. 2003. Water use of mature Thompson Seedless grapevines in California. Irrig. Sci. 22:11-18

Winkler, A.J., J.A. Cook, W.M. Kliewer, and L.A. Lider. 1974. General viticulture. University of California Press, Berkeley, CA

Wolpert, J.A., P.A. Phillips, R.K. Striegler, M.V. McKenry, and J.H. Foott. 1993. Berber orchardgrass tested as cover crop in commercial vineyard. Calif. Agr. 47:23-25. 